Apidologie, 1976, 7 (1), 61-66.

\title{
THE EFFECTS OF DIFFERENT HUMIDITIES ON THE HATCHING OF THE EGGS OF HONEYBEES
}

\author{
Keith M. DOULL \\ Waite Agricultural Research Institute \\ The University of Adelaide \\ Adelaide, S.A.
}

\begin{abstract}
SUMMARY
The effects of different levels of R.H. on the hatching of the eggs of honeybees has been studied. The optimum range for normal hatching was found to be between 90 and $95 \%$ R.H. There was a significant decline in the number of normal larvae that emerged when eggs were incubated at $100 \%$ and $80 \%$ R.H. At $50 \%$ R.H. many eggs shrivelled and of the remainder, only $2.9 \%$ produced normal larvae. No eggs hatched at humidities below $50 \%$ R.H. Abnormal hatching was found to be due to failure of the hatching fluid to dissolve that part of the chorion covering the heads of the larvae. Practical implications of the results of the experiments are discussed.
\end{abstract}

\section{INTRODUCTION}

When small nucleus hives are maintained in flight cages in summer, most eggs fail to hatch. Provision of water inside the hive remedies this condition, and normal broodrearing is resumed. (Doull, unpub. obs.)

That the hatching of the eggs of the honeybee is affected at too high an ambient humidity was noted by DU PRAw (1961). He reported that when the egg hatches, the chorion splits in the equatorial plane, releasing the hatching fluid which dissolves the chorion. If free water is present in the cell, the portion of the chorion enclosing the head of the larvae remains intact. The larva are unable to free themselves from the remnants of the chorion, and die after a few hours. Du Praw suggested that the hatching fluid might be diluted 
in the high humidity of the cell, and so lose its ability to dissolve the remainder of the chorion.

It may well be that the hatching fluid would evaporate too quickly if ambient humidity was too low. This would produce a result similar to that described by Du Praw for excessively high humidities. A study has been carried out to test this proposition.

\section{MATERIALS AND METHODS}

Eggs of known age were obtained by placing the queen bee on a single empty comb in a queen excluder cage in the centre of the broodnest of her hive. This operation was carried out in the evening and the comb containing eggs up to 12 hours old was removed the following morning.

The eggs were removed from the cells and were placed on black filter paper that had been dipped in molten beeswax. The filter papers, each with $100 \mathrm{eggs}$, were placed in dessicators at desired humidites and were incubated at $35{ }^{\circ} \mathrm{C}$.

The eggs were examined after 24 hours. This identified those eggs that had been damaged during the transfer operation.

In all replicates, a proportion of eggs failed to show any initial signs of embryonic development. These eggs were considered to be non-viable, and together with eggs that had been damaged were eliminated from the records.

\section{RESULTS}

The results are summarized in Table 1 . This shows numbers of eggs that hatched, and the number and percentage that produced normal larvae.

TAB. 1. - Numbers of normal larvae that hatched from honeybee eggs at $35^{\circ} \mathrm{C}$ and at seven different levels of R.H.

\begin{tabular}{c|c|c|c}
$\begin{array}{c}\text { Relative } \\
\text { Humidity }\end{array}$ & $\begin{array}{c}\text { No. of eggs } \\
\text { hatehed }\end{array}$ & \multicolumn{2}{|c}{$\begin{array}{c}\text { Normal larvae } \\
\text { No. }\end{array}$} \\
\hline & & & $\%$ \\
\hline 100 & 307 & 201 & 65.4 \\
95 & 433 & 428 & 98.81 \\
90 & 292 & 270 & 92.4 \\
80 & 254 & 151 & 59.53 \\
70 & 246 & 11 & 4.5 \\
50 & 136 & 4 & 2.9 \\
40 & 0 & - & \\
30 & 0 & - & \\
20 & 0 & &
\end{tabular}

1. Difference between $100 \%$ and $95 \%$ is significant $(\mathrm{P}=<0.01)$.

2. Difference between $95 \%$ and $90 \%$ is not significant (P $-<0.001)$.

3. Difference between $90 \%$ and $80 \%$ is significant (P. $=<0.0001)$. 
At all humidities below $50 \%$ R.H., all eggs that had shown initial embryonic development at 24 hours were completely shrivelled at 72 hours.

At $50 \%$ R.H., $46 \%$ of eggs were shrivelled at 72 hours. The remaining $54 \%$ hatched.

At humidities of $50 \%$ R.H. and above, two categories of larvae were recognized after hatching :

1. Eggs hatched to produce larvae with the characteristic smooth shiny cuticle over the whole body. The complete outline of the head capsule was distinguishable, and no remnants of the chorion remained. These were recorded as Normal Larvae resulting from complete hatching of the egg.

2. Eggs hatched, but while the abdomen and thorax showed the characteristic shiny smooth cuticle, the head capsule and at times part of the thorax had a different appearance. The surface of the body in these parts was dull and relatively rough, and the outline of the head capsule was obscured. This dull rough surface showed characteristic reticulations and was clearly the remains of the chorion. These were regarded as Abnormal Larvae, resulting from incomplete hatching of the egg.

When the proportions of eggs producing Normal Larvae after incubation at different levels of humidity are considered, the effects of humidity on hatching become quite clear.

The optimum range of humidity for complete hatching of the egg of the honeybee lies between $90 \%$ and $95 \%$ R.H. These data support the proposition that the chorion of the honeybee egg is not completely dissolved when eggs hatch at humidities that are below the optimum range.

These results raise some questions on aspects of the collection and use of water by honeybees.

The intensity of water collection is greatest in colonies that are rearing brood. It is stated that water is used for temperature control, and in general terms “ for broodrearing ). (PARK 1923). PARK (1949) also suggested that water would be required to maintain c relatively high levels of humidity in the broodnest so that the larvae would not dry out ".

However, according to HAYDAK (1943) larvae up to three days old float on food containing 65-74\% water. Moreover, combs containing larvae are normally well covered with bees and this might be expected to reduce direct loss of moisture from the cells. In general it would appear that larvae of any age would not normally be exposed to dangerously low levels of humidity.

Park (1949) discussed the "water storage bees" that are present on the brood combs and their activities of depositing hanging droplets of water in the cells. Perhaps one function of these bees would be in the maintenance of the necessary humidities in cells containing eggs. 
It is unlikely that humidities in the optimum range for successful hatching of the eggs - 85-95\% - would be favourable for other activities of the colony, or that they would occur generally throughout the hive in summer.

The problem of accurate measurement of humidities within the hive has yet to be solved. Available sensors are not completely adequate and the presence of sensing equipment often affects the behaviour of the bees.

During these experiments a long-probe direct reading hair hygrometer was placed between combs of brood in a hive in full sun. Humidities ranged between $60 \& 70 \%$ R.H. over a period of two days. By this time, the bees had begun to cover the probe with wax and propolis and the readings became unreliable. These levels agree with those suggested by OERTEL (1949).

Whatever may be the basic factors involved in the maintenance of optimum humidities within the broodnest, there are some practical implications to the results of these experiments.

Koeniger (reported by Van Praagh, 1972) finds it necessary to maintain a sponge containing water in colonies in flight rooms. A similar practice is adopted by the author with colonies in flight cages, while LeNsKy (1964) found that colonies in a glasshouse increased their rate of broodrearing when water was available inside the hive.

With field colonies, TABER et al (1974) found that the provision of water inside the hives exposed to insecticide was one means of assisting the colonies to maintain broodrearing.

None of these reports provides information as to the relative proportions of eggs, larvae and pupae in the test hives. It is probable that the provision of water inside the test hives created conditions that allowed the eggs to hatch properly. However, this cannot be proven from the available evidence.

Information from recent observations of colonies in lucerne fields in South Australia (WINN, pers. comm.) provides some further evidence. The fields were sprayed with parathion late in the day when foraging had almost ceased. On the following day, minor losses of bees were recorded. Some 3000-4000 dead bees appeared outside each colony. The populations of the colonies were estimated to range between 50,000 and 55,000 bees, so that the dead bees did not constitute a major proportion of the field force of any hive.

However, foraging from the colonies was markedly reduced, and in particular there was a substantial reduction in the number of bees collecting water. The intensity of both foraging and water collection recovered after 48 hours.

Subsequent examination of the brood chamber disclosed a "break" in broodrearing, and it was clear that few new larvae had appeared for the first few days after the fields had been sprayed. 
This provides evidence of the effects of interference with foraging and particularly with water collection on the amounts of brood reared in the colony. Observations on flight behaviour of bees from colonies in flight cages and glasshouses show a substantial interference with foraging as many bees try to escape from confinement (Doull, unpub. obs.).

The maintenance of the correct balance of age groups is important for the consistent development of a honeybee colony. Any interference with broodrearing must always lead to some imbalance in the proportions of the various " age groups" and must exert detrimental effects on all aspects of colony biology. Thus interference with mechanisms controlling the collection of water must represent a significant hazard to honeybee colonies.

Further studies on this topic are warranted. Such studies should include regular records of numbers of eggs, larvae and pupae if they are to provide positive and reliable information.

Reçu pour publication en novembre 1975.

Eingegangen im November 1975

\section{REFERENCES}

Du Praw E. J., 1961. A unique hatching process in the honeybee. Trans. Amer. Micr. Soc., 80, 185-191.

HAYDaK M. H., 1943. Larval food and development of castes in the honeybee. J. Econ. Ent., 36, $778-792$.

Lensky Y., 1964. Les régulations thermiques dans la ruche en été. Ann. Abeille, 7, 23-35.

Oertec E., 1969. Relative humidity and temperature within the beehive. J. Econ. Ent., 42, 528-31.

PArK O. W., 1923. Water stored by bees. Amer. Bee J., 63, 348-349.

PARK O. W., 1949. The hive and the honeybee. Datan \& Sons, Hamilton, Illinois.

Taber S. T. III, J. MiLls, E. Ce 1974. Colonies of honeybees : survival in insecticide treated Arizona cotton fields through colony management. J. Econ. Ent., 67, 41-73.

Van Praagh J. P., 1972. Towards a controlled environment room suitable for normal colony life of honeybees. J. Apic. Res., 11. 77-78.

\section{ZUSAMMENFASSUNG}

\section{DER EINFLUSS VERSCHIEDENER LUFTFEUCHTIGKEIT}

AUF DAS SChlüPfEN DER BIENENEIER (Apis mellifica L.)

Bieneneier bekannten Alters wurden durch Absperren einer legenden Königin auf einer Wabe inmitten ihres Brutnestes erhalten. Die Eier wurden auf Filterpapier übertragen, das in geschmolzenes Wachs getaucht worden war. Sie wurden dann im Brutschrank bei $35^{\circ} \mathrm{C}$ und unterschiedlicher Feuchtigkeit gehalten. Die Ergebnisse wurden nach 72 Stunden festgestellt.

War die relative Feuchtigkeit geringer als $50 \%$, schrumpften alle Eier ein und kamen nicht zum Schlüpfen. Bei $50 \%$ iger rel. F. schrumpfte ein hoher Anteil der Eier, und vom Rest 
erbrachten nur 2,9\% normale Maden. 90-95\% rel. F. erschienen als das Optimum für das Schlüpfen. Die Ursache des unnormalen Schlüpfens bei weniger als $90 \%$ rel. F. wird darin gesehen, dass die Flüssigkeit beim Schlüpfen nicht ausreicht, den Teil des Chorions aufzulösen, der den Kopf und manchmal auch den Thorax bedeckt. Die Maden waren nicht imstande, sich selbst von den Resten des Chorions zu befreien und starben ab. Bei den mikroskopischen Untersuchungen wurden diese Chorionreste am matten Aussehen der Madenköpfe und am Netzwerk, das dem Chorion des Bieneneies eigen ist, nachgewiesen.

\section{RÉSUMÉ}

\section{INFLUENCE DE L'HYGROMÉTRIE SUR L'ÉCLOSION DES CEUFS D'ABEILLE}

L'obtention d'œufs d'abeille d'âge connu est réalisée en plaçant au centre du nid à couvain d'un rayon une reine en cours de ponte dans une cage munie d'une grille à reine. On transpose les œufs sur du papier filtre trempé dans de la cire d'abeille et on les soumet à l'incubation à $35^{\circ} \mathrm{C}$ et à différents degrés d'hygrométrie. On note les résultats 72 heures plus tard.

Lorsque l'hygrométrie relative est inférieure à $50 \%$, tous les oufs se ratatinent et aucun ne parvient à éclore. A $50 \%$ d'hygrométrie relative une forte proportion se ratatine et seulement $2,9 \%$ des restants produisent des larves normales. Le domaine optimum pour l'éclosion s'étend de 90 à $95 \%$ d'hygrométrie relative. L'éclosion anormale en dessous de $90 \%$ d'hygrométrie relative est provoquée par le liquide d'éclosion qui ne parvient pas à dissoudre la portion du chorion qui couvre la tête, et parfois le thorax, de la larve. Les larves sont incapables de se libérer elles-mêmes des restes du chorion et meurent. Ceux-ci ont été identifiés par l'aspect mat que revêtent à l'examen microscopique les têtes des larves et par les réticulations présentes sur le chorion des ceufs. 